\title{
STUDIES IN ENGLISH LEGAL HISTORY. AN INTRODUCTION
}

\begin{abstract}
In this article, the general goals of the following volume of the journal were defined. It was described how Polish-English commercial and political relations evolved. Besides, a short history of the Polish lawyers' interest in English law was presented. Finally, the author referred to the outcomes of the research of Polish scholars who were studying English legal history in the last half a century.
\end{abstract}

Keywords: England; Poland; Legal History; Cooperation.

The times when the history of English law was a subject of legal research, undertaken solely by the representatives of Anglo-American legal tradition, has passed irrevocably. A brief glance of the programmes of the biggest legal history conference devoted, inter alia, to the subject of English legal tradition - British Legal History Conference - shows that the history of English law is undertaken by scholars across the world.

For non-common law lawyers, the English law is very often a fascinating story of different methods, visions and ways of approaching the law. Since the very first year of their legal studies, the future continental lawyers are impregnated with the belief that the English law or common law is something totally different. Nonetheless, many are interested in the details of those differences.

In the following issue of the Acta Universitatis Lodziensis. Folia Iuridica, several articles devoted to the subject of English legal history are presented. The main aim of this collection was to assemble the texts that illustrate different epochs and problems of English legal history. The variety of methods and methodologies present in these articles demonstrate how the development of the English legal system is a rich field of study.

In addition, another equally important purpose of collecting the following articles was to furnish the space for international dissemination of the research findings of both common law and Polish researchers who are working in the field of English legal history.

The Polish-English legal relations, however, cannot be treated as a new phenomenon. On the contrary, that can be dated back at least

${ }^{*}$ University of Łódź, Faculty of Law and Administration, Department of Roman Law, lukasz. korporowicz@wpia.uni.lodz.pl. 
to the eighteenth-century, while the Polish-English political and economic mutual relations are even older. As far back as 1415, Henry V of England wrote a letter to Polish King Władysław Jagiełło asking "for his military assistance" during the war with King of France (Halicki 1934, 660). In the next centuries, the relations were not very vibrant, but they definitely existed. In the late sixteenth-century an anonymous British author wrote Relation of the State of Polonia and the United Provinces of that Crown Anno 1598, which was edited and published half a century ago by Charles H. Talbot (1965). Finally, it cannot be forgotten that the trade relations between the two countries in the sixteenth and most of the seventeenthcenturies was performed through the English Eastland Company (Hinton 1959). Certainly, an important factor in strengthening these political and commercial relations was an establishment of fixed diplomatic relations by the mid-eighteenth century between both countries (Libiszowska 1966).

As to the matter of law, in the mid-seventeenth century Arthur Duck published his treaty De usu et authoritate iuris civilis romanorum, where he presented the legal systems of different European states, including Poland. A century later, Thomas Bever spoke about Polish law and Polish constitutionalism during his Oxford civil law lectures (Korporowicz 2019). At the same time, Polish legal authors demonstrated an increased interest in England. The most visible sign of that was the Polish translation of the fourth book of William Blackstone's Commentaries published in 1786 by Teodor Ostrowski. Although the translation was based not on Blackstone's original text, but rather on a 1776 French translation by Gabriel-François Coyer (see Bartel 1987). In the nineteenth century, Polish legal authors were eager to make a comparative analysis in their works. English law was used as an example, analogy or simply as a comparative tool. Even brief analysis of the Polish legal and historical works of the epoch shows frequent reference to England, its law and its social organisation (see e.g. such authors as Tadeusz Czacki, Leon Winiarski and Antoni Szymański).

The most systematic Polish work devoted to the English law was, however, a book published in 1944 by Polish émigré lawyer Gustaw Rosenberg (1944). Before the Second World War, he was an advocate in Kraków and then in Warsaw. Shortly before the outbreak of the war he left Poland and settled in London, where he became a barrister. As it was mentioned above, in 1944 the Fortune Press published his textbook of English law. It was a concise work that dealt with all the fundamental aspects of the English legal system. It was divided into three parts: (1) Civil law, (2) Criminal law and (3) The Establishment of Justice and the Court Procedure. The goals of Rosenberg's work are not entirely clear. It is possible that he might have hoped the book would be used by the students of the Polish Faculty of Law which was functioning at Oxford University during the war and immediately after it (Cywiński, Rojewski, and Tomporowski 1997).

In the post-war period, Polish curiosity in English law became even stronger. It is possible, however, to observe a shift in the area of these interest. In the earlier 
epochs, Polish scholars were predominantly interested in the then modern English law. Since at least the 1960s, English legal history became a predominant field of study. It was initiated by Wojciech Maria Bartel with his studies regarding the protection of personal liberty in Anglo-Saxon England (Bartel 1965). A history of English criminal law became a subject of numerous studies undertaken since the 1970s until recently by another law professor from Kraków - Kazimierz Baran (for the list of his works see: Halberda 2014). His disciple is Jan Halberda, a prolific scholar whose scholarship is focused on the history of English contracts and quasicontracts. The civilian tradition of English law is currently researched by two Polish scholars: Łukasz Marzec from Jagiellonian University and by the writer of these words. Besides this, there a number of other scholars who occasionally direct their research attention towards certain aspects of English law and British constitutionalism.

Articles collected in the foregoing volume can be divided into four thematic segments. Methodological matters connected with the research on English legal history were presented by Cerian Charlotte Griffiths (on the difficulties regarding the use of Old Bailey Online database) and Thomas Glyn Watkin (on what should be the main point of interest for the legal history researchers). The doctrinal framework of the English law and its studies were the subjects of research undertaken by Tomasz Tulejski (on Samuel Rutherford's political thought) and Michael Stuckey (on the importance of John Mitchell Kemble for the nineteenth-century English legal historiography). John Patrick Higgins has discussed the similarities of the contexts that led to the creation of English Magna Carta and Polish Księga Elblaska. His work presents a comparative methodology. And finally, the civilian influence on English law is the subject of an article published by Łukasz Jan Korporowicz (the reference to the Rome and Roman law during the slavery abolition struggles).

It is hoped that the following selection of texts will encourage and inspire further fruitful cooperation between researchers from common law countries and from Poland, in order to mutually contribute to the subject of English legal history.

\section{BIBLIOGRAPHY}

Bartel, Wojciech M. 1965. Ochrona wolności osobistej na tle rozwoju państwowości anglosaskiej Brytanii. Kraków: Uniwersytet Jagielloński.

Bartel, Wojciech M. 1987. "Knowledge of the English Criminal Law in Poland at the Turn of the Eighteenth and Nineteenth Century". In The Political Context of Law. Proceedings of the Seventh British Legal History Conference, Canterbury 1985. Edited by Richard Eales, David Sullivan. 106-112. London and Ronceverte: The Hambledon Press.

Cywiński, Janusz W., Tadeusz S. Rojewski. Wiesław Tomporowski. 1997. Monografia Polskiego Wydziału Prawa 1944-1947. London: Polska Fundacja Kulturalna.

Halberda, Jan. 2014. "Dorobek naukowy Profesora dr hab. Kazimierza Barana”. Krakowskie Studia z Historii Państwa i Prawa 7 (1): 7-10. 
Halicki, Oskar. 1934. "Anglo-Polish Relations in the Past”. The Slavonic and East European Review 12 (36): 659-669.

Hinton, Raymond W.K. 1959. The Eastland Trade and the Common Weal in the Seventeenth Century. Cambridge: Cambridge University Press.

Korporowicz, Łukasz J. 2019. "Thomas Bever o prawie w dawnej Polsce”. Studia Prawnicze KUL 4 (80). Forthcoming.

Libiszowska, Maria. 1966. Misja polska w Londynie w latach 1769-1795. Łódź: Prace Łódzkiego Towarzystwa Naukowego.

Rosenberg, Gustaw. 1944. Podręcznik prawa angielskiego. London: The Fortune Press.

Talbot, Charles H. 1965. "Relations of the State of Polonia and the United Provinces of that Crown. Anno 1598". In Elementa ad fontium editiones XIII. Res Polonicae ex Archivo Musei Britannici. I Pars. Roma: Institutum Historicum Polonicum Romae.

\section{Łukasz Jan Korporowicz}

\section{STUDIA Z HISTORII PRAWA ANGIELSKIEGO. WPROWADZENIE}

Streszczenie. W artykule wskazano na cele towarzyszące wydaniu niniejszego numeru czasopisma. Omówiono rozwój relacji handlowych i politycznych łączących Polskę i Anglię. Ponadto przedstawiono krótką historię zainteresowania polskich prawników prawem angielskim. Na koniec, autor odniósł się do wyników badań polskich naukowców badających w ciągu ostatniego półwiecza historię prawa angielskiego.

Slowa kluczowe: Anglia; Polska; historia prawa; współpraca. 